\title{
TH1 VERSUS TH17 IN CHRONIC HEPATITIS C VIRUS INFECTION
}

\author{
By \\ Mohammed Saaed El-Shorbagy, Salama Saad Abd El-Latif*, \\ Runia Fouad El-Folly ** and Rasha Reda Zaater ***
}

Clinical Pathology Department, Al Azhar University*, Tropical Medicine Department, Ain Shams University** and Clinical Pathology Department, Ain Shams University***

\begin{abstract}
Background: Hepatitis C virus (HCV) is a major cause of chronic liver disease affecting close to 170 million people worldwide. Egypt Demographic Health Surveys (EDHS) measured antibody prevalence among adult population aged $15-59$ years at $14.7 \%$ in 2009 and at $10.0 \%$ in 2015 . Approximately, $85 \%$ of patients acutely infected with HCV progress to chronic liver disease with persistence of HCV RNA for more than 6 months. Among patients with chronic HCV infection, 15-20\% progress to end-stage liver disease and approximately $14 \%$ of these patients progress to cirrhosis or hepatocellular carcinoma with time. With hepatitis $\mathrm{C}$, being a national care problem, predicting the outcome of treatment in these patients becomes very important.

Objectives: The aim of this study was to evaluate and predict the response in hepatitis $\mathrm{C}$ virus patients to pegylated interferon alpha and ribavirin therapy in association with estimation of the percentage of TH1 and TH17 by flowcytometry.

Patients and Methods: This study was conducted on 50 patients with proven chronic hepatitis $\mathrm{C}$ virus infection based on by PCR technique and histopathology ( 25 responders and 25 non-responders). All of them were treated by combined pegylated interferon alfa plus ribavirin orally. Patients with history of previous interferon therapy, evidence of other systemic illness including: (hepatic, renal, cardiac, diabetic and neoplastic disease), chronic inflammatory disease, unstable thyroid dysfunction, unstable psychiatric disorder or history of any organ transplantation were excluded. All patients were F2or F3 on fibroscan. By flowcytometry, human CD4 percentage was estimated by using fluorescein-conjugated antibody. Human TH17 percentage was estimated by using PerCP-conjugated antibody, and TH1 was estimated by phycoerythron conjugated antibody. Both TH1 and TH17 were performed at weeks 0 and retested again after 12 weeks.
\end{abstract}

Results: After 12 weeks from starting of therapy, there was an increase in percentage of TH1 in nonresponders of therapy compared to responders with no difference in the percentage of TH17 between the two groups.

Conclusion: There was a positive correlation between TH1 and TH17 in both groups before and after therapy. Also, we found that $98 \%$ of patients achieved sustained virological response 12 weeks after completion of therapy $\left(\mathrm{SVR}_{12}\right)$ showed sustained virological response 24 weeks after completion of therapy $\left(\mathrm{SVR}_{24}\right)$.

Key words: Hepatitis C virus, immunological response, TH1, TH17, IFN, causes of resistance. 


\section{INTRODUCTION}

Hepatitis C virus (HCV) is a global health problem characterized by persistent infection, limited therapeutic options, poor treatment responses, and no available vaccine. Following years of intensive research into the pathogenesis of $\mathrm{HCV}$, it has become evident that this virus is able to modulate host immunity, in particular $\mathrm{T}$ cell responses and by doing so facilitates chronic infection. The mechanisms by which $\mathrm{HCV}$ impairs antiviral $\mathrm{T}$ cell immunity include blunted $\mathrm{T}$ cell activation and proliferation by up-regulating inhibitory pathways, skewed $\mathrm{T}$ cell differentiation (Th1 deficiency or Th2 dominance), $\mathrm{T}$ cell anergy (antigenspecific hypo-responsiveness or exhaustion), $\mathrm{T}$ cell depletion (cell apoptosis or death), and induction of regulatory $\mathrm{T}$ cells (Xiao et al., 2013).

$\mathrm{T}$ helper (Th17) cells are a discovered TH cell subset with implications in both host defense and autoimmunity. Th17 implications in chronic HCV infection are not well characterized. Given the important role in multiple other immune and inflammatory conditions, they are of obvious interest. Specific HCV-Th17 cells are implicated in immune response modulation, correlated with fibrosis severity and intrahepatic inflammatory status. Serum IL-17 levels are higher in chronic HCV infected patients and Th17 cytokines are modulated within the therapeutic response at anti-viral treatment. However, intriguing data indicate that Th17 could be associated with spontaneous HCV clearance. It is possible that Th17 could play a dual role (both beneficial and harmful) and that an unbalance of regulating factors (chemokines, transcription factors, receptor expression, etc.) rather than the lymphocyte itself could tip the Th17 immune response one way or another (Baianescu et al., 2012).

Early detection of non-responders and continuing treatment for patients who are more likely to respond is of major importance in improving the outcome of patients with chronic $\mathrm{HCV}$ infection. Hence, accurate prediction of treatment response after 12 weeks of therapy associated with immunogenic role of proinflammatory T cells (TH1 \& TH17) have become a major factor in the management algorithm for chronic $\mathrm{HCV}$ infection (Navaneethan et al., 2009).

The aim of the present work was to evaluate and predict the response in hepatitis $\mathrm{C}$ virus patients to pegylated interferon alpha and ribavirin therapy in association with estimation of the percentageof TH1 and TH17 by flowcytometry.

\section{PATIENTS AND METHODS}

This control study was conducted in Al-Hussein hospital throughout the period between June 2014 and June 2016. Patients enrolled in the current study were consecutively enrolled from Al-Qahera El-Fatmia hospital. This study was conducted on 50 patients with proven chronic hepatitis $\mathrm{C}$ virus infection based on by PCR technique and histopathology. All patients were F2 and F3 on liver biopsy. They were 2 groups of patients:

Group I (25 patients) showed $\mathrm{SVR}_{12}$ (HCV RNA below detection limit after 12 weeks of treatment). 
Group II (25 patients) did not respond to treatment after 12 weeks of treatment.

Both groups were treated weekly by pegylated interferon alpha $180_{\mathrm{ugm}}$, in addition to weight-based Ribavirin daily for 12 weeks.

Inclusion criteria: Adult patients aged 25 to 55 years with documented chronic HCV infection.

Exclusion criteria: Pregnancy or breastfeeding females, history of previous interferon therapy, evidence of other systemic illness including hepatic, renal, cardiac, diabetic and neoplastic disease, chronic inflammatory disease, unstable thyroid dysfunction, unstable psychiatric disorder, or history of any organ transplantation.

An informed consent was obtained from all participants before recruitment in the study and before any invasive procedure. Approvals of all the concerned authorities were obtained.

For all patients, the following were done:

A full medical history including age, sex, history of schistosomiasis or viral hepatitis, exposure to high risk factors, history suggestive of liver cell failure or other disorders, e.g. D.M., and also any special habits like smoking or alcohol intake.

Thorough clinical examination for assessment BMI and examination of the abdomen (Liver size and consistency, spleen and ascites).

Assessing of fibrosis stage was done through FIB-4 calculation.

Fibroscan and Liver biopsy.
The following Laboratory tests were done before and after 12 weeks of treatment:

Complete blood picture (Sysmex KX21N-Japan), ALT\&AST (Randox u.v. method- United Kingdom), total bilirubin, s.albumin and s.creatinine (Randox Colorimetric method- United Kingdom), prothrombin time and INR (Sysmex CA600-Japan), quantitative PCR (ThermoScientific, Germany, Lot 00459337), ANA, HBsAg, HIV (BIORAD Elisa- USA), TSH and AFP (Cobas 6000-Germany), TH1 and TH17 by flowcytometry (R\&D SYSTEMS - USA).

\section{Specimen collection:}

$10 \mathrm{ml}$ of venous blood were withdrawn from all subjects by venipuncture under complete aseptic condition and divided into multiple tubes each with suitable anticoagulants for estimation of CBC, PT, blood chemistry and also TH1, Th17 by flowcytometry.

Statistical methods: Data analysis were performed using IBM SPSS statistics software version 22.0, IBM Corp., Chicago, USA, 2013. Descriptive statistics were done for quantitative data as minimum and maximum of the range as well as mean $\pm \mathrm{SD}$ (standard deviation) for quantitative normally distributed data, while it was done for qualitative data as number and percentage. Inferential analyses were done for paired t-test in cases of two dependent groups with normally distributed data. Correlations were done using Pearson correlation for numerical normally distributed data. Logistic regression model was used to find out independent factors affecting response. The level of significance was taken at $P$ value $\leq 0.05$. 


\section{RESULTS}

Among non-responders, TH1 significantly increased after treatment (Table 1).

Table (1): Laboratory findings before and after treatment among responders and non-responders

\begin{tabular}{|c|c|c|c|c|c|}
\hline \multicolumn{2}{|c|}{ Variable } & & Before & After & $\mathbf{P}$ \\
\hline \multirow{4}{*}{ TH1 \% } & \multirow[t]{2}{*}{ Responders } & Mean \pm SD & $40.8 \pm 16.8$ & $41.1 \pm 19.4$ & \multirow{2}{*}{0.952} \\
\hline & & Range & $4.1-63.8$ & $10.5-79.0$ & \\
\hline & \multirow{2}{*}{$\begin{array}{l}\text { Non- } \\
\text { responders }\end{array}$} & Mean \pm SD & $44.6 \pm 14.1$ & $53.8 \pm 16.1$ & \multirow{2}{*}{$0.010 *$} \\
\hline & & Range & $15.7-71.4$ & $22.7-84.0$ & \\
\hline \multirow{4}{*}{ TH17 \% } & \multirow[t]{2}{*}{ Responders } & Mean \pm SD & $13.5 \pm 10.1$ & $13.3 \pm 8.5$ & \multirow{2}{*}{0.937} \\
\hline & & Range & $0.1-39.8$ & $1.0-30.4$ & \\
\hline & \multirow{2}{*}{$\begin{array}{l}\text { Non- } \\
\text { responders }\end{array}$} & Mean \pm SD & $17.8 \pm 10.7$ & $17.9 \pm 9.1$ & \multirow{2}{*}{0.974} \\
\hline & & Range & $3.3-39.8$ & $4.7-34.4$ & \\
\hline \multirow{4}{*}{$\begin{array}{c}\text { HCV } \\
\text { RNA } \\
\left(x 10^{6} / \mathrm{ml}\right)\end{array}$} & \multirow[t]{2}{*}{ Responders } & Mean \pm SD & $2.0 \pm 2.6$ & $0.0 \pm 0.0$ & \multirow{2}{*}{$<0.001 *$} \\
\hline & & Range & $0.1-9.6$ & $0.0-0.0$ & \\
\hline & \multirow{2}{*}{$\begin{array}{l}\text { Non- } \\
\text { responders }\end{array}$} & Mean \pm SD & $1.2 \pm 1.9$ & $0.7 \pm 1.0$ & \multirow{2}{*}{0.283} \\
\hline & & Range & $0.1-8.1$ & $0.1-4.4$ & \\
\hline
\end{tabular}

There was significant positive correlation between TH1 and TH17 before treatment among both responders and non-responders (Table 2).

Table (2): Correlations between laboratory findings before treatment among responders and non-responders.

\begin{tabular}{|c|c|c|c|c|}
\hline \multicolumn{2}{|c|}{ Variables } & Measure & TH1\% & TH17\% \\
\hline \multirow{4}{*}{ TH17\% } & Responders & $\mathrm{r}$ & 0.772 & - \\
\cline { 3 - 5 } & & $\mathrm{p}$ & $<0.001^{*}$ & - \\
\cline { 3 - 5 } & $\begin{array}{c}\text { Non- } \\
\text { responders }\end{array}$ & $\mathrm{r}$ & 0.756 & - \\
\cline { 3 - 5 } & \multirow{3}{*}{ Responders } & $\mathrm{p}$ & $<0.001 *$ & - \\
\cline { 3 - 5 } & \multirow{3}{*}{\begin{tabular}{c} 
Nib4 \\
\cline { 2 - 5 }
\end{tabular}} & $\mathrm{r}$ & -0.063 & 0.095 \\
\cline { 2 - 5 } & responders & $\mathrm{p}$ & 0.766 & 0.651 \\
\cline { 3 - 5 } & $\mathrm{r}$ & -0.139 & -0.161 \\
\hline
\end{tabular}

There was significant positive correlation between TH1 and TH17 before treatment among both responders and non-responders (Table 3). 
Table (3): Correlations between TH1, TH 17 and laboratory findings after treatment among responders and non-responders.

\begin{tabular}{|c|c|c|c|c|}
\hline \multicolumn{2}{|c|}{ Variables } & Measure & TH1\% & TH17\% \\
\hline \multirow{4}{*}{ TH17 \% } & \multirow[t]{2}{*}{ Responders } & $\mathrm{r}$ & 0.773 & - \\
\hline & & $\mathrm{p}$ & $<0.001 *$ & - \\
\hline & \multirow{2}{*}{$\begin{array}{l}\text { Non- } \\
\text { responders }\end{array}$} & $\mathrm{r}$ & 0.734 & - \\
\hline & & $\mathrm{p}$ & $<0.001 *$ & - \\
\hline \multirow{4}{*}{$\begin{array}{c}\text { AFP } \\
(\mathrm{ng} / \mathrm{ml})\end{array}$} & \multirow[t]{2}{*}{ Responders } & $\mathrm{r}$ & 0.547 & 0.047 \\
\hline & & $\mathrm{p}$ & 0.688 & 0.077 \\
\hline & \multirow{2}{*}{$\begin{array}{c}\text { Non- } \\
\text { responders }\end{array}$} & $\mathrm{r}$ & 0.212 & 0.062 \\
\hline & & $\mathrm{p}$ & 0.309 & 0.770 \\
\hline
\end{tabular}

Different variables had no significant diagnostic performance in predicting responding condition after treatment and there was no statistical significant difference among responders and non-responders according to radiological findings before treatment (Table 4).

Table (4): Diagnostic performance of different variables in predicting responding condition after treatment.

\begin{tabular}{|c|c|c|c|c|}
\hline Variables & AUC & SE & P & 95\% CI \\
\hline AFP (ng/ml) & 0.505 & 0.084 & 0.954 & $0.500-0.670$ \\
\hline $\begin{array}{c}\text { HCV RNA } \\
\text { (x106/ml) }\end{array}$ & 0.656 & 0.078 & 0.059 & $0.502-0.810$ \\
\hline Fib4 & 0.512 & 0.084 & 0.884 & $0.500-0.676$ \\
\hline TH1 \% & 0.547 & 0.082 & 0.567 & $0.500-0.709$ \\
\hline TH17 \% & 0.604 & 0.081 & 0.207 & $0.500-0.762$ \\
\hline
\end{tabular}

$98 \%$ of patients achieved $\mathrm{SVR}_{12}$ showed $\mathrm{SVR}_{24}$.

\section{DISCUSSION}

Our target was to fix most of the predictor factors as possible between responders and non-responders to identify some cellular immunological markers associated with SVR as prestep to modulate immune response in that direction to improve clinical management (Navaneethan et al, 2009). The cellular immune response against $\mathrm{HCV}$ is induced in acute $\mathrm{HCV}$ infection by NK cells while in chronic stage by CD8 cytotoxic T cells 
mainly. Both effector subsets and regulatory lymphocytes are found in the liver of chronic $\mathrm{HCV}$, and the balance of the cells recruited will determine the severity of the liver disease. The pathogenesis of chronic $\mathrm{HCV}$ disease which lead to liver damage is suggested to be due to dysregulated immune response with exaggerated proinflammatory cytokines released mainly by $\mathrm{TH} 1$ and TH17 compared to anti-inflammatory cytokines released from $\mathrm{Th} 2$ and Treg. (Balanescu et al., 2012).

It is documented that TH17 and TH1 cells are developmentally related. Furthermore, Romagnani., 2008 observed the presence in the circulation $\mathrm{TH}$ cells that can produce IL-17 and IFN-gamma as well as the flexibility of human TH17 clones to produce IFN- gamma in addition to IL-17 in response to IL-12. MacDonald et al., 2002 stated that specific TH17 and TH1 cells are induced against the core protein in HCV infection. Additionally, to its potent proinflammatory capacity, IL-17 exerts its effects through facilitating $\mathrm{T}$ cell infiltration, activation and amplification of the immune response by inducing production of IL-6. In addition, IL-17 synergizes with other cytokines, in particular with IL-1 $\beta$ and tumor necrosis factor (TNF)- $\alpha$ (Balanescu et al., 2012).

Interferon-gamma (IFN- $\gamma$ ), as one of the TH1 related cytokine, has elicited great interest in chronic viral infections because it is abundantly produced and has direct antiviral activity. The pathogenesis of viral chronic liver disease that leads to liver damage is suggested to be immunemediated (Barakat et al., 2012). It has been shown that patients with chronic hepatitis $\mathrm{C}$ virus (HCV) infection display a polarized NK cell phenotype with IFN- $\gamma$ production and that kinetics of NK, with IFN gamma production, to alpha IFN therapy will be important in $\mathrm{HCV}$ management (Ahlenstiel et al., 2010).

In our results, before treatment there was no difference in TH1 percentage between responders and non-responders. 12 weeks after treatment with pegylated IFN and ribavirin, TH1 cells level were higher in non-responders compared to responders. This is going with studies done by Jimenez-Sousa et al., (2010), Fathy et al., (2011) and Lu et al., (2016) who observed that patients of HCV under pegylated IFN and Ribavirin therapy with increased IFN-gamma failed to achieve RVR compared to $\mathrm{HCV}$ patients with decreased IFN-gamma levels. The refractory effect to exogenous alpha IFN may be attributed to direct effect of excess endogenous alpha IFN through induction of intracellular suppression factors, e.g. suppressor of cytokine signalling 3 (SOCS3) as homeostatic mechanism at cellular level.

The variation in TH1 activity could be attributed to drug effect. In chronic hepatitis $\mathrm{C}$ patients who were treated by pegylated IFN and ribavirin showed marked decreased activity of TH1 (expression of gamma IFN) which is not secondary to reduction of viral load since no correlation was found between $\mathrm{HCV}$ RNA and IFN gamma level but it was mediated by Ribavirin as no modification of IFN gamma expression was seen in patients treated with alpha IFN alone and there was no modulation of IL2, IL4, IL10 expression found in patients treated with INF alone or in combination with ribavirin (Bergamini et al., 2009). This variation in 
TH1 activity could be attributed to viral effect. Hepatitis $\mathrm{C}$ induces immunosuppressive cytokines IL-10 and TGF-B, which are able to inhibit TH17, TH1 and inhibition of intrahepatic IFN-gamma production by HCV NS5A (Kanda et al., 2009). In addition, defective IFN- gamma production by peripheral blood mononuclear cells was observed in $\mathrm{HCV}$ infected patients in response to nonstructural protein 4 (Fathy et al., 2011). It has been observed that HCV NS3-specific T cells do not proliferate during treatment of chronic $\mathrm{HCV}$ infection with ribavirin in combination with IFN-a and proliferated after stopping of treatment (Bergamini et al., 2009). in addition, the variation of TH1 activity could be due to tolerogenic effect of liver tissue. In chronic $\mathrm{HCV}$ infection a weak CD4+/CD8+ T cell response is observed. The tolerogenic potential of the liver, may be caused by either a primary $\mathrm{T}$ cell failure in which the dendritic cells fail to stimulate the antigen-specific $T$ cells, or $T$ cell exhaustion in which virus-specific $\mathrm{T}$ cells become depleted by a continuous high viral load (Fathy et al., 2011).

Contradictory studies done by Barakat et al. (2012) who found increase in IFN gamma level in responders compared to non-responders with significant correlations between IFN and HCV viral load as assessed by PCR as well as liver condition which assessed by high ALT. In vitro and in murine models, ribavirin may prime human $\mathrm{T}$ cell for an increased production of TH1 cytokines, such as IFN-g and IL-2, which play a key role in antiviral responses. On the basis of these findings it has been suggested that ribavirin may potentiate IFN-a activity against $\mathrm{HCV}$ by immune-mediated mechanisms. The capacity of ribavirin to potentiate the anti-HCV effect of IFN-a is better explained by its ability to increase up to $6^{\prime} 1$ fold the intracellular levels of the bioactive enzyme 2',50oligoadenylatesynthetase, which mediates most of the antiviral effects of IFN-a, with respect to the levels obtained by IFN-a alone (Martin et al., 1998).

Increased circulating TH17 and intrahepatic HCV-specific TH17 cells were observed in chronic $\mathrm{HCV}$ patients. HCV-specific TH17 cells were correlated with severity of liver inflammation in chronic HCV patients and positively correlated with ALT, but not with viral load. Serum IL-17 levels were higher in chronic HCV patients when compared to controls. However, no association was found between serum IL-17 concentration, ALT levels and viral load (Chang et al., 2012). Another study showed that IL-17A, IL-17F, and IL-22 are produced by CD4+ and CD8+T cells at significantly higher levels within the liver as compared to peripheral blood. A greater proportion of intra-hepatic lymphocytes co-secreted IL22 along with IL-17 than in the peripheral blood. The roles of IL-17 and IL-22 are not completely understood, but the higher co-expression of IL-22 may function as a feedback that diminishes IL-17-mediated inflammation (Foster et al., 2012).

In our study we did not find difference in the percentage of TH17 between responders and non-responders before and after treatment. Also, there was positive correlation between TH1 and TH17 in responders and non-responders before and after 12 weeks of therapy by pegylated interferon and ribavirin. This is going with study done by Hao et al. (2014) who 
observed that the percentage of TH17 cells and IL-17, IL-22 and IL-23 concentrations did not change during therapy in either responder or nonresponder. On the contrary study done by Balanescu et al. (2012) found that IL-17 levels were elevated in the serum of chronic HCV patients and values did not correlate with viral loads following 12 weeks of treatment with IFN- $\alpha$ and ribavirin and that the increase in IL17 levels could also play a part in hepatic viral persistence by means of antiapoptotic molecules upregulation. IFN- $\gamma$ showed significant reduction after 12 weeks of treatment in contrast to IL-17 serum levels and no difference was observed between responders and nonresponders. Kim et al. (2009) observed that the increase in TH17 could be attributed to $\mathrm{HCV}$ effect. HCV proteins modify the differentiation of peripheral monocytes into mature dendritic cells (DC)s. HCV core protein and NS3 protein interfere with the process of DCs maturation. During in vitro differentiation of monocytes into DCs, the presence of either core or NS3 protein caused downregulation of $\mathrm{CD} 1 \mathrm{a}$ and $\mathrm{CD} 1 \mathrm{~b}$ and these effects were dose-dependent. These two proteins could be engaged in a form of immune subversion, impairing the normal differentiation of DCs (Tu et al., 2012). This abnormal DC differentiation determined a skew towards TH17 cell subset differentiation that might be implicated in liver injury related to the viral infection. Other studies found that serum IL17 cytokine was reduced after 12 weeks of therapy and responders showed greater cytokine decline. This may be attributed to reciprocal increase in Treg as there is plasticity between Treg and TH17, so It is possible that $\mathrm{TH} 17$ could play a dual role and not TH17 itself, but a misbalance of its regulating factors (chemokines, transcription factors, receptor expression, etc.) could direct TH17in one way or another (Balanescu et al., 2012). Also, we found that $98 \%$ of patients achieved sustained virological response 12 weeks after completion of therapy $\left(\mathrm{SVR}_{12}\right)$ showed sustained virological response 24 weeks after completion of therapy $\left(\mathrm{SVR}_{24}\right)$, this is going with studies done by Burgess et al. (2016).

\section{CONCLUSION}

There was an increase in percentage of TH1 in non-responders of therapy (pegylated interferon alpha and ribavirin) after 12 weeks from starting of therapy compared to responders with no difference in the percentage of TH17 between the two groups, and there was a positive correlation between $\mathrm{TH} 1$ and TH17 in both groups before and after therapy. $98 \%$ of patients achieved $\mathrm{SVR}_{12}$ showed $\mathrm{SVR}_{24}$. We recommend extended studies to explore the immunological role of proinflammatory $\mathrm{T}$ cells (TH1 and TH17) associated with $\mathrm{SVR}_{12}$ to improve the clinical management.

\section{REFERENCES}

1. Ahlenstiel G1, Titerence RH, Koh C, Edlich B, Feld JJ, Rotman Y, Ghany MG, Hoofnagle JH, Liang TJ, Heller $\mathrm{T}$ and Rehermann B (2010): Natural killer cells are polarized toward cytotoxicity in chronic hepatitis $\mathrm{C}$ in an interferon-alfa-dependent manner. Gastroenterology, 138: 321-322.

2. Bălănescu P, Lădaru A, Voiosu T, Nicolau A, Ene M and Bălănescu E (2012): Th17 and IL-17 Immunity in Chronic Hepatitis C Infection. Rom.J.intern. med., 50(1): P.13-18. 
3. Barakat A, Hegazy A, Farag R, Abdul Baky A, Arafa L and Farouk A (2012): Role of Interferon-gamma and Immune Response Biomarkers in Predicting IFN-alpha Responsiveness and Treatment Outcome in Patients with Hepatitis C Virus. International Journal of Virology, 8: 288-298.

4. Bergamini A, Bolacchi F, Cepparulo M, Demin F, Uccella I, Bongiovanni B, Ombres D, Angelico F, Liuti A, Hurtova M, Francioso S, Carvelli C, Cerasari G, Angelico $M$ and Rocchi $G$ (2009): Treatment with ribavirin and interferon-a reduces interferon-g expression in patients with chronic hepatitis C. Clin Exp Immunol., 123(3):459464.

5. Burgess S, Hussaini T and Yoshida $E$ (2016): Concordance of sustained virologic response at weeks 4,12 and 24 post-treatment of hepatitis c in the era of new oral direct-acting antivirals. A concise review. Ann Hepatol., 15:154-159.

6. Chang Q, Wang Y, Zhao Q, Wang C, Hu Y and Wu B (2012): Th17 cells are increased with severity of liver inflammation in patients with chronic hepatitis C. J. Gastroenterol. Hepatol., 27: 273-278.

7. Fathy A, Ahmed A, Metwally L and Hassan A (2011): $\mathrm{T}$ Helper Type 1/T Helper Type 17Related Cytokines in Chronic Hepatitis C Patients before and after Interferon and Ribavirin Therapy. Med PrincPract., 20:345349.

8. Foster R, Golden-Mason L, Rutebemberwa A and Rosen $H$ (2012): Interleukin (IL)-17/IL22-producing $\mathrm{T}$ cells enriched within the liver of patients with chronic hepatitis $\mathrm{C}$ viral (HCV) infection. Dig Dis Sci., 57:381-389.

9. Hao C, Zhou Y, He Y, Fan C, Sun L, Wei X, Wang $L$, Peng M, Wang P, Lian J and Jia $Z$. (2014): Imbalance of regulatory $T$ cells and $T$ helper type 17 cells in patients with chronic hepatitis C. Immunology, 143(4):531-538.

10. Jimenez-Sousa M, Almansa R, de la Fuente C, Caro-Paton A, Ruiz L, Sanchez-Antol? G, Gonzalez J, Aller R, Alcaide N, Largo P, Resino S, de Lejarazu $R$ and BermejoMartin J (2010): Increased Th1, Th17 and profibrotic responses in hepatitis C-infected patients are down-regulated after 12 weeks of treatment with pegylated interferon plus ribavirin. European Cytokine Network, 21: 8491.

11. Kanda $T$, Steele $R$, Ray $R$ and Ratana $R$ (2009): Inhibition of intrahepatic gamma interferon production by hepatitis $\mathrm{C}$ virus nonstructural protein 5A in transgenic mice. $\mathrm{J}$ Virol., 83: 8463-8469.

12. Kim B, Hou W and Kang H (2009): Th 17 cells enhance viral persistence and inhibit $\mathrm{T}$ cell cytotoxicity in a model of chronic virus infection. J Exp Med., 206: 313-28.

13. Lu M, Huang C, Dai C, Wang $S$, Hsieh $M$, Hsieh M, Liang P, Lin Y, Hou N, Yeh M, Huang C, Lin Z, Chen S, Huang J, Chuang $W$ and Yu M (2016): Elevated on-treatment levels of serum IFN-gamma is associated with treatment failure of peginterferon plus ribavirin therapy. Scientific Reports, 6:22995.

14. MacDonald A, Duffy M, Brady M, McKiernan S, Hall W, Hegarty J, Curry M and Mills K (2002): CD4 T helper type 1 and regulatory $\mathrm{T}$ cells induced against the same epitopes on the core protein in hepatitis $\mathrm{C}$ virusinfected persons. J Infect Dis., 185:720-727.

15. Martin J, Navas S, Quiroga J, Pardo $M$ and Carre?o V (1998): Effects of the ribavirininterferon a combination on cultured peripheral blood mononuclear cells from chronic hepatitis C patients. Cytokine, 10:635-644.

16. Navaneethan $U$, Kemmer $\mathbf{N}$ and Neff $G$ (2009): Predicting the probable outcome of treatment in $\mathrm{HCV}$ patients. Therap Adv Gastroenterol., 2(5) 287-302.

17. Romagnani S (2008): Human Th17 cells. Arthritis Res Ther., 10 (2): 206-223.

18. Tu Z, Hamalainen-Laanaya $H$ and Nishitani C (2012): HCV core and NS3 proteins manipulate human blood-derived dendritic cell development and promote Th 17 differentiation. Int Immunol., 24(2):97-106.

19. Xiao J, Cheng J, Jia M, Xiao Y, Toshiro N, Mitsumi H, Jonathan P and Zhi Q (2013): Immunomodulatory role of the hepatocyte during $\mathrm{HCV}$ infection: driving CD4+CD25+Foxp3+ Regulatory $\mathrm{T}$ cell Development through the Tim-3/Gal-9 Pathway. Eur. J. Immunol., 43(2): 458-467. 


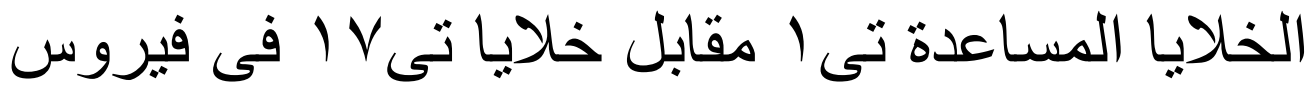 الإلتهاب الكبدى الوبائي سى أنى}

محمد سعيد الثوريجى* ـ سلامة سعد عبد اللطيف* ـ رنيا فؤاد الفولى *** ـ رشا رضازعتر *** قسم الباثولوجيا الإكلينيكية بكلية الطب ـ جامعة الأزهر* رقسم الأمراض المتوطنة بكلية الطب ـ جامعة عين شمس*

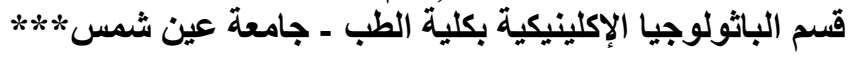

خلفية البحث : فيروس الالتهاب الكبدي الوبائي سى هو أحد الأسباب الرئيسية لأمر اض الكبد المزمنة

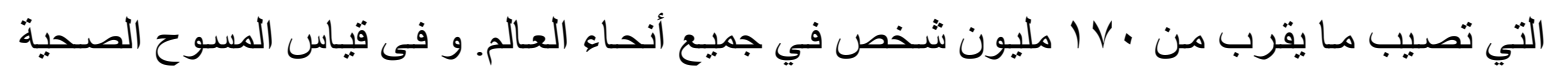

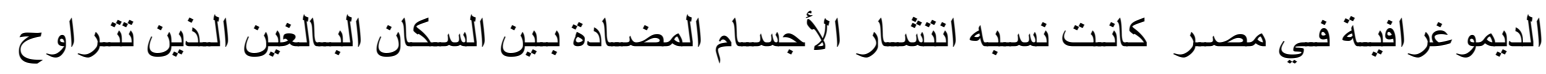

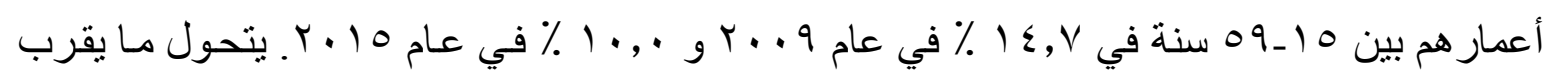

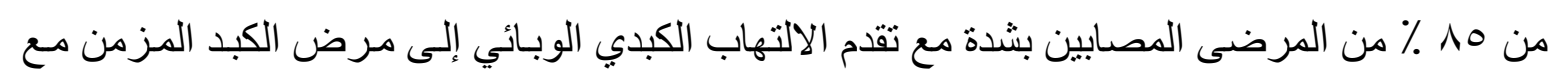

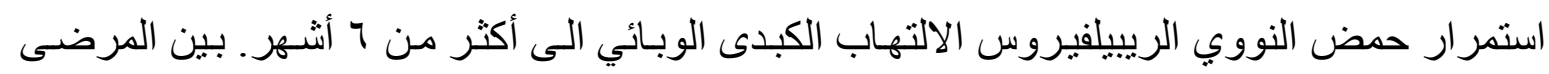

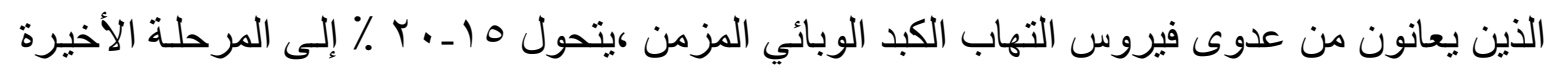

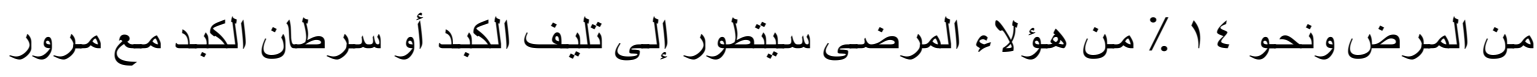

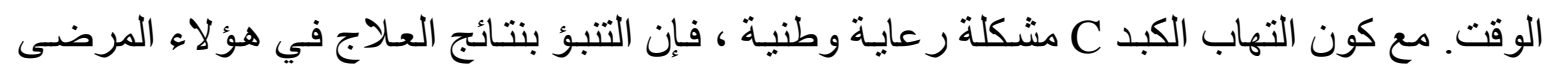
يصبح مهمًا جدًا.

الهدف من البحث: الهذف من هذه الدراسة هو تقيبم وتوقع الاستجابة في مرضى فيروس التهاب الكبد

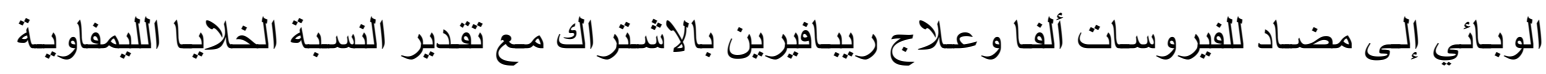

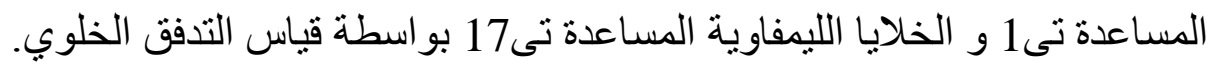

المرضى وطرق البحث: أجريت هذه الدراسة على ، ه مريضًا مصابًا بعدوى فيروس التهاب الكبد

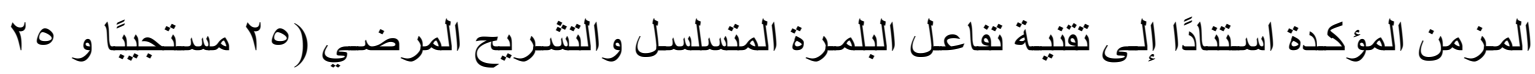

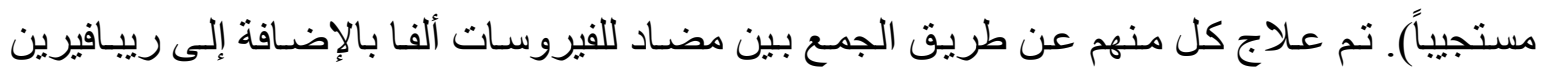

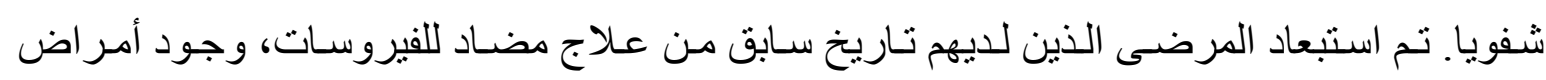

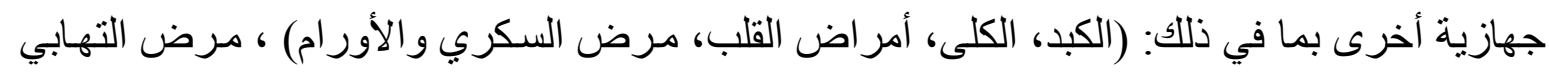

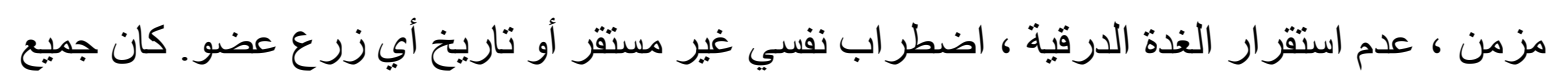

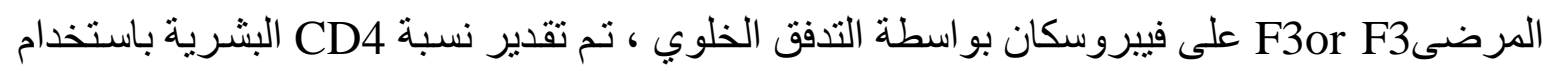

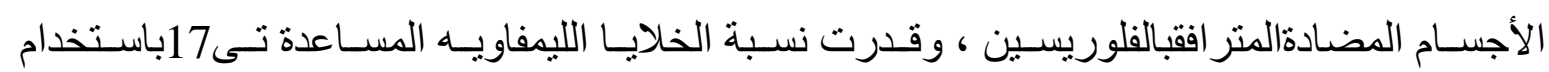

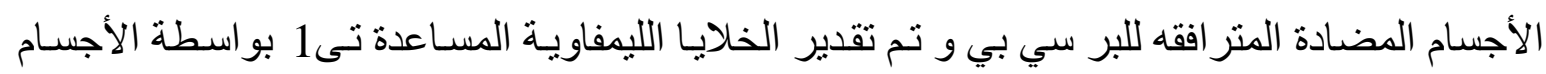


المضادة المتر افقة فيكو ايريثرون. نم إجر اء كل من الخلايا الليمفاوية المساعدة تىى1 والخلايـا الليمفاويـة

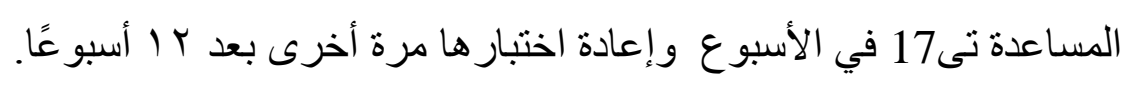

النتائج: بعد ب أسبو عا من بدء العلاج كان هناك زيادة في نسبة الخلايـا الليمفاويـة المسـاعدة تى1 في

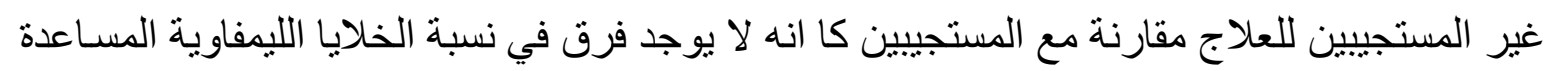
تى17 في بين المجمو عتين. الاستنتاج: كان هناك ارتباطاً إيجابياً بين الخلايا الليمفاوية المساعدة تى1 و الخلايا الليمفاويـة المساعدة

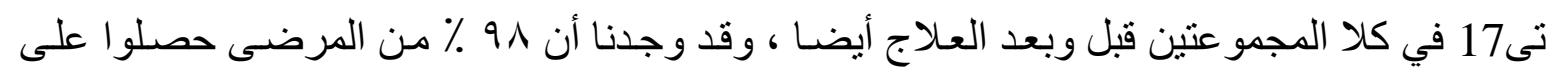

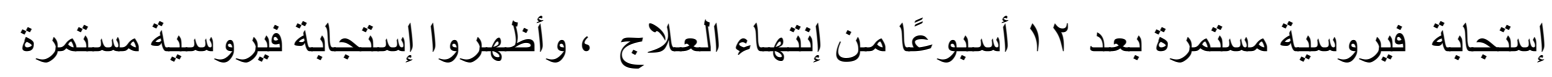
بعد \& أسبو عًا من إنتهاء العلاج. 